\title{
A
}

Acta HealthMedica

Acta HealthMedica (ISSN: 2414-6528)

http://www.ActaHealthMedica.com

Volume 3, Issue 1, February 2018, Pages: 248, DOI: http://dx.doi.org/10.19082/ah248

\section{EPIDEMIOLOGY AND FORMATION OF FUNGAL BIOFILMS AND SUSCEPTIBILITY TESTING OF CANDIDA GLABRATA ISOLATED ON ENDOSCOPES IN THE DEPARTMENT OF GASTROENTEROLOGY AT THE UNIVERSITY HOSPITAL OF TLEMCEN}

\author{
Imane Lahfa-Hassaine ${ }^{1}$, Zahia Boucherit-Otmani ${ }^{1}$, Kebir Boucherit ${ }^{1,2}$.
}

1: Laboratory Antibiotics Antifungals: Physical Chemistry, Synthesis and Biological Activity (LapSab), Department of Biology, Faculty of SNV-STU, University Aboubekr Belkaïd. Tlemcen Algeria

2: University center of Belhadj Bouchaib, Ain Temouchent

imanebio90@yahoo.fr

\section{TYPE OF ARTICLE: CONFERENCE ABSTRACT}

\begin{abstract}
Background: Candidosis is the most prevalent opportunistic fungal infection of humans. It causes a variety of damages ranging from superficial mucosal diseases to deep-seated mycoses. It represents the leading cause of invasive candidiasis characterized by significant morbidity and mortality in critically ill patients. Among candida species, Candida albicans is the most common pathogen isolated and responsible for the majority of superficial and systemic infections. However, it appears that nonalbicans species such as Candida glabrata are emerging in mycoses infections. A major virulence factor of Candida sp. is its ability to form surface-attached microbial communities known as biofilms. Candida biofilms can develop on medical devices. The clinical significance of biofilms is highlighted by recent estimates that over $65 \%$ of all hospital infections originate from these microbial communities

Aim: The aim of our study is to look for fungal infection linked to the species Candida glabrata on endoscopes at the University Hospital of Tlemcen. Then to determinate the minimum inhibitory concentrations of sessile cells (SMIC) of isolated strains against amphotericin B.

Methods: A total of 300 samples on endoscopes were performed over a period of 3 years. After isolation, purification and identification of strains, antifungal susceptibility tests for C. glabrata biofilm against amphotericin B were carried out according to Pierce et al., 2008.

Results: Of the 300 samples taken, 12 strains of Candida glabrata were isolated ( $28 \%$ of isolates).

It also appears from this study that the minimum inhibitory concentrations for sessile cell (SMIC) strains isolated against amphotericin B are between 1 and $16 \mu \mathrm{g} / \mathrm{mL}$.

Conclusion: It appears from this study that the fungal infections on medical devices are widely present in hospitals. The presence of Candida glabrata is not negligible; they are present on $28 \%$ of endoscopes. Amphotericin B is the first line of antifungal for the treatment of candidiasis, indeed, most of our strains are sensitive to it.

KEYWORDS: Candidiasis, Fungal infections, Amphotericin B, Candida glabrata, SMIC
\end{abstract}

\footnotetext{
Abstracts of Second International Conference on Health Sciences and Medical Technologies, 10-12 October 2017, Tlemcen, Algeria (ICHSMT-17)

(C) 2018 The Authors. This is an open access article under the terms of the Creative Commons Attribution-NonCommercialNoDerivs License, which permits use and distribution in any medium, provided the original work is properly cited, the use is non-commercial and no modifications or adaptations are made.
} 